Journal of Biomedical and Pharmaceutical Research

Available Online at www.jbpr.in

CODEN: - JBPRAU (Source: - American Chemical Society)

PubMed (National Library of Medicine): ID: (101671502)

Volume 8, Issue 3: May-June: 2019, 50-53
ISSN (Online): 2279-0594

ISSN (Print): 2589-8752

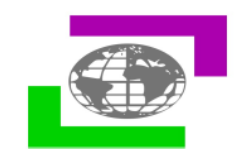

\title{
ASSESSMENT OF ANTIMICROBIAL ACTIVITY OF AZADIRACHTA INDICA FROM MAHALAPURAM, JAIPUR
}

Sweta Mishra, Vishnu Sharma*, Rincy Yesudas, Ritu Singh Rajput

Department of Food \& Biotechnology, Jayoti Vidyapeeth Women's University, Jaipur, India

Article Info: Received 28 April 2019; Accepted 02 June. 2019

DOI: https://doi.org/10.32553/jbpr.v8i3.606

Address for Correspondence: Dr. Vishnu Sharma, Assistant professor, Department of Biotechnology, Jayoti Vidyapeeth Women's University, Jaipur

Conflict of interest statement: No conflict of interest

\section{ABSTRACT:}

The medicinal plants have been used for years in daily life to treat infections all over the world. Azadirachta indica is a very valuable traditional therapeutic plant in the sub-continent regions. Each part of the tree has remarkable medicinal properties. In the present study, Phytochemical study yielded positive results for tannins, cardiac glycosides, anthraquinones, and saponins. The terpenoids was found to be missing. In antimicrobial studies, the organic and aqueous Leaf extract of Azadirachta indica found to show inhibitory action against the growth of Staphylococcus aureus and Escherichia coli that reveal the presence of pharmacologically bioactive constituents in Azadirachta indica.

Key words: Nature; Azadirachta indica; Ayurveda; antimicrobial activity

\section{INTRODUCTION}

Nature provides us the botanical wealth that supplies the basic requirements of the universe in form of food, therapeutic components, clothing, and shelter (Rastogi and Mehrotra, 2002; Vaidya, 1997; Aiyegoro and Okoh, 2009). Since the Vedas time, plants are using as medicine in mode of Homeopathy, Allopathy, Unani and Ayurvedic medicine (Jawla et al., 2009; Husain et al., 1992).There is Sushruta Samhita, Charaka Samhita and Bhagvat are three preliminary texts which build the base of Ayush and milestone in medical sciences (Sharma et al., 2014; Nair and Chanda, 2007). From the opening of 20th century, allopathic systems of medicine have popularity among people, which was based on fast therapeutic actions of synthetic drugs but unfortunately, it has several side effects. Due to it, the present route of the healthcare system is being changed from synthetic to herbal trend. It is termed as "Return to Nature" (Krishnaraju et al., 2005; Singh, 2007).

The natural remedies by plants have assorted data of phytochemicals and essential oils which reveals therapeutics importance for human (Krishna et al., 2008; Sharma et al., 2014). Azadirachta indica is the one of important, fast-growing, evergreen tree belongs to the family Meliaceae which is widely used as "SARVA ROGA NIVARINI" in Ayurveda from more than 4000 years due to its medicinal properties. It has long been respected by ancient Indian people and is labeled "Village Drugstore" (Orwa et al., 2009). In the present study, aim was to evaluate the antimicrobial activity of Azadirachta indica against clinically important bacteria Staphylococcus aureus, and E. coli.

\section{Material and methods:}

In the present study, organic (ethanol, chloroform, hexane) and aqueous extracts were extracted from shade dried leaves of Azadirachta indica plant using Soxhlet apparatus. Each extract was applied to evaluate Antibacterial activity against E. coli (ATCC25922) and Staphylococcus aureus (ATCC25923) (Nwachukwu et al., 2006). The experimental work was performed at the Department of Biotechnology, Jayoti Vidyapeeth Women's University, Vedant Valley, Mahalapuram, Jaipur, Rajasthan. 


\section{Anti-Microbial Assay:}

Antibacterial activities of the aqueous and organic extracts were analyzed by agar well diffusion method (Gould and Bowie, 1952). Microbial suspensions of E. coli (ATCC25922) and Staphylococcus aureus (ATCC25923) were prepared by suspending overnight incubated old bacterial culture in sterile normal saline $(0.89 \% \mathrm{NaCl}$ wt/vol) separately. The turbidity of the microbial suspension was adjusted to 0.5 McFarland standards (equivalent to $1.5 \times 108 \mathrm{CFU} / \mathrm{ml}$ ). Then $0.1 \mu \mathrm{l}$ of microbial suspension was spreaded over the surface of solidified NA plates with the help of sterile cotton swabs. Then, the wells $(6 \mathrm{~mm}$ in diameter) were prepared using a sterile cork borer on the nutrient agar plates with inoculums and the each extracts (ethanol, chloroform, hexane and aqueous) were inserted in wells separately and allowed to be diffuse for 24hrs. Respectively organic solvents were used for calculation of negative activity and Amikacin (30 mcg/disc), cefixime $(5 \mathrm{mcg} / \mathrm{disc})$, vancomycin $(30 \mathrm{mcg} / \mathrm{disc})$, clindamycin $(2 \mathrm{mcg} / \mathrm{disc})$ were used as standard controls. After incubation period plates were observed for the formation of zone of inhibition $(\mathrm{mm})$ (including the width of the well). The activity index was also calculated. Phytochemical examination:

In the present study, the phytochemical screening was analyzed using standard procedures to identify the constituents as described by Dash et al., 2017 and Ramadass and Subramanian, 2018. Phytochemical tests were done to find the presence of the active chemical constituents such as anthraquinones terpenoids flavonoids saponins, tannins, cardiac glycosides.

\section{Results \& Discussion:}

In the present study, the therapeutic potential was focused on the medicinal plant Azadirachta indica selected from Mahalapuram, Jaipur. Results of the primary photochemical analysis of leaves of Azadirachta indica showed that the tannins, cardiac glycosides, anthraquinones, and saponins are present in $A$. indica. The Terpenoids was found to be absent (Table-1).

Table-1:- Preliminary screening of phytochemicals in Azadirachta indica.

\begin{tabular}{|l|l|l|}
\hline Sr. No. & Name of Phytochemical & Status \\
\hline 1. & Cardiac glycosides & + \\
\hline 2. & Tannins & + \\
\hline 3. & Terpenoids & - \\
\hline 4. & Anthraquinones & + \\
\hline 5. & Flavonoids & + \\
\hline 6. & Saponins & + \\
\hline
\end{tabular}

Present +, Absent -

The findings of the present study are in line of Kumar et al., (2018) who reported the presence of flavonoids, glycosides, tannins, saponins from neem leaves. The results of E. Raphael (2012) were not found to be exactly similar to our results. The differences between studies were due to the climatic condition, soil and temperature and also due to area or the region from where the plant material collected.

In antimicrobial studies, different organic and aqueous extracts from Azadirahta indica were found to be exhibited great potential of antibacterial activity against Staphylococcus aureus and Escherichia coli microorganisms tested. The results are cited in table- 2 .

Table 2: Antibacterial activity of $A$. indica leaves extracts against $E$. coli and $S$. aureus.

\begin{tabular}{|c|c|c|c|c|c|c|c|c|c|c|}
\hline \multirow{4}{*}{$\begin{array}{l}\text { Extracts } \\
(50 \mu \mathrm{l} / \text { well) }\end{array}$} & \multicolumn{10}{|c|}{ Zone of inhibition (in $\mathrm{mm}$ ) } \\
\hline & \multicolumn{5}{|c|}{ Escherichia coli } & \multicolumn{5}{|c|}{ Staphylococcus aureus } \\
\hline & \multirow{2}{*}{$\begin{array}{l}\text { Inhibition } \\
\text { Zone (in } \mathrm{mm} \text { ) }\end{array}$} & \multicolumn{4}{|c|}{ Activity index } & \multirow{2}{*}{$\begin{array}{l}\text { Inhibition Zone } \\
\text { (in } \mathrm{mm} \text { ) }\end{array}$} & \multicolumn{4}{|c|}{ Activity index } \\
\hline & & Amk & Clin & Cefm & Vancn & & Amk & Clin & Cefm & Vancn \\
\hline Ethanol & $12.5 \pm 1.41$ & 0.58 & 0.55 & 0.82 & 1.04 & $15.0 \pm 1.41$ & 0.70 & 0.67 & 0.98 & 1.25 \\
\hline Chloroform & $10.5 \pm 1.75$ & 0.49 & 0.47 & 0.69 & 0.87 & $11.5 \pm 1.76$ & 0.53 & 0.51 & 0.75 & 0.96 \\
\hline Hexane & $10.0 \pm 1.40$ & 0.46 & 0.44 & 0.65 & 0.83 & $15.0 \pm 1.41$ & 0.69 & 0.67 & 0.98 & 1.25 \\
\hline Aqueous & $<6$ & 0.28 & 0.27 & 0.39 & 0.5 & $<6$ & 0.28 & 0.27 & 0.39 & 0.5 \\
\hline
\end{tabular}

However, a comparison showed that ethanol extracts of Azadirachta indica have a greater potential of antibacterial activity than those of other extracts (Table-2 \& Graph-1). The ethanol extracts exhibited the highest zone of inhibition against S.aureus of (IZ: $15.0 \mathrm{~mm}$ ) followed by E.coli (IZ: $12.5 \mathrm{~mm})$. 


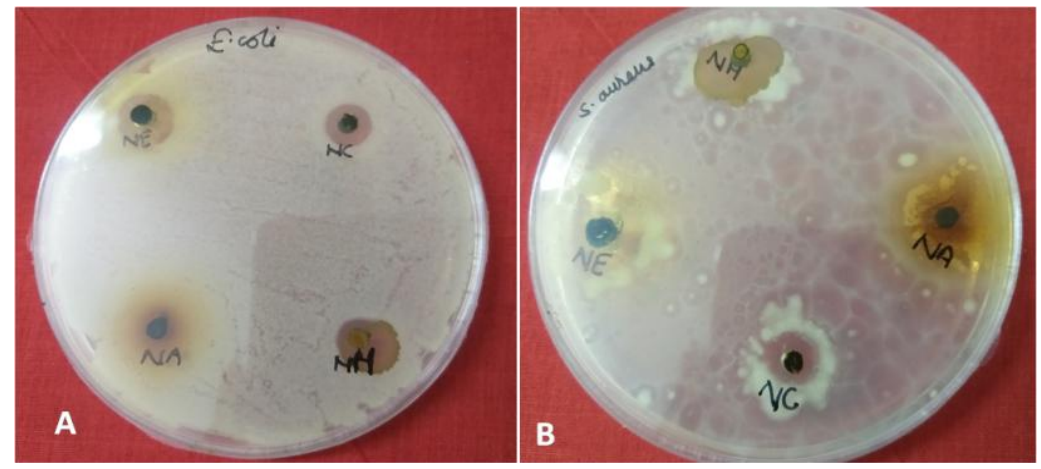

Figure 1: Antimicrobial activity of Aazadirachta indica against (A) E. coli (B) S. aureus.

However, Chloroform extracts exhibited its highest zone of inhibition of (IZ: $11.5 \mathrm{~mm}$ ) against S.aureus followed by E.coli (IZ: $10.5 \mathrm{~mm}$ ). Hence the hexane extracts were found to exhibit the zone of inhibition of (IZ: $15.0 \mathrm{~mm}$ ) against $S$. aureus and of (IZ: $10.0 \mathrm{~mm}$ ) against E.coli. The highest activity index was found to relate with reference antibiotic as vancomycin followed by cefixime.

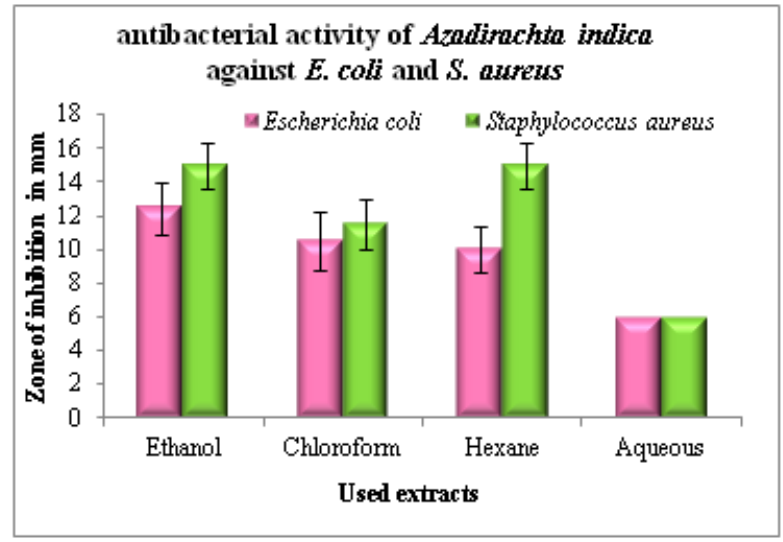

Graph 1: Antibacterial activity of Azadirachta indica against against E. coli \& S. aureus.

Our outcomes are in support of Emran et al., 2015 who reported that the crude organic extract of Azadirachta indica leaves exhibited the antimicrobial activity against both $E$. coli and $S$. aureus. In continous, In a study by Farjana et al. (2014), the antibacterial activity of water, oil and methanol extracts of neem (Azadirachta indica) against Escherichia coli and Staphylococcus aureus bacteria reported a similarity with our findings and showed that Out of all used extract boiled water extract of neem leaf moderate zone of inhibition against Escherichia coli $(10 \mathrm{~mm})$ while less effective against Staphylococcus aureus.

The results of this study showed that the organic extracts were more effective than aqueous extracts. This possibly will be due to the superior solubility of the active components in organic solvents (de Boer et al., 2005) and similar used for our studied. In Conclusion, variable extracts of Azadirachta indica have therapeutic compounds that possess wide spectra of antimicrobial activity. The results showed that the organic and aqueous extracts of Neem leaves were also able to inhibit the microbial growth used in this study with different degrees of inhibition. Further, pharmacological studies are required to construct actual herbals in treating various microbial infections and diseases.

\section{Acknowledgement:}

The authors are indebted to Department of Food \& Biotechnology, Jayoti Vidyapeeth Women's University, Jaipur. A grateful acknowledgment is to Post Graduate Institute of Medical Education \& Research, Chandigarh for supply the clinical microbial isolates.

\section{References:}

1. Aiyegoro, O.A. and Okoh, A.I., (2009) Use of bioactive plant products in combination with standard antibiotics, implications in 
Dr. Vishnu Sharma et al., Journal of Biomedical and Pharmaceutical Research

antimicrobial chemotherapy. J Med Plants, 3, 1147-1152.

2. Dash, S.P., Dixit, S. and Sahoo, S. (2017) Phytochemical and Biochemical Characterizations from Leaf Extracts from Azadirachta Indica: An Important Medicinal Plant, Biochem Anal Biochem 6, 323. doi: 10.4172/2161-1009.1000323

3. De Boer, H.J., Kool, A., Broberg, A., Mziray, W.R., Hedberg, I. and Levenfors, J.J. (2005) Antifungal and Antibacterial activity of some herbal remedies from Tanzania, J. Etnopharm, 96, 461-469.

4. Raphael, E. (2012) phytochemical constituents of some leaves extract of Aloevera and Azadirachta indica plant species, Global Advanced Research Journal of Environmental Science and Toxicology, 1(2), 014-017.

5. Emran, T.B., Nasir, U.M.M., Rahman, A., Uddin, Z. and Islam, M. (2015) Phytochemical, Antimicrobial, Cytotoxic, Analgesic and AntiInflammatory Properties of Azadirachta indica: A Therapeutic Study, J Bioanal Biomed, S12, 007

6. Farjana, A., Zerin, N. and Kabir, Md. S. (2014) Antimicrobial activity of medicinal plant leaf extracts against pathogenic bacteria, Asian Pacific Journal of Tropical Disease, 4(2), S920S923

7. Gould, J.C. and Bowie, J.H. (1952) The determination of bacterial sensitivity to antibiotics, Edinburgh medical journal, 59, 178-99

8. Husain, A., Virmani, O.P., Popli, S.P., Misra, L.N., Gupta, M.M., Srivastava, G.N., Abraham, Z. and Singh, A.K. (1992) Dictionary of Indian Medicinal Plants, CIMAP, Lucknow, India, 546.

9. Jawla, S., Gupta, A.K., Singla, R., and Gupta V. (2009)General awareness and relative popularity of allopathic, ayurvedic and homeopathic systems, Journal of Chemical and Pharmaceutical Research, 1(1),105-112.

10. Krishna, K.L., Paridhavi, M. and Patel, J.A. (2008) Review on Nutritional, Medicinal and Pharmacological properties of papaya (Carica papaya Linn.), 7(4), Rev., 364-373.

11. Krishnaraju, A.V., Rao, T.V.N., Sundararajua, D., Vanisreeb, M., Tsayb, H.S. and Subbarajua,
G.V. (2005) Assessment of bioactivity of Indian medicinal plants the using brine shrimp (Artemia salina) lethality assay, International Journal of Applied Science and Engineering, 2(3), 125-134

12. Nair, R. and Chanda, S.V. (2007) Antibacterial activities of some medicinal plants of the Western Region of India, Turkish Journal of Biology, 31, 231-236.

13. Nwachukwu, C.B., Azoro, C., Idris, A. and Woken, G.N. (2006) Antimicrobial activity of methanol and aqueous leaf extracts of Mitracarpus scaber on Staphylococcus aureus. Bioscience, Biotechnology Research Asia, 3(2a), 305-308.

14. Orwa, C., Mutua, A., Kindt, R., Jamnadass, R. and Anthony, S., (2009) Agroforestree Database: a tree reference and selection guide version 4.0, (http://www.worldagroforestry.org/sites/tree dbs/treedatabases.asp)

15. Ramadass, N. and Subramanian, N. (2018) Study of phytochemical screening of neem (Azadirachta indica), International Journal of Zoology Studies, 3(1), 209-212

16. Kumar, R., Sharma, S. and Devi, L. (2018) Investigation of Total Phenolic, Flavonoid Contents and Antioxidant Activity from Extracts of Azadirachta indica of Bundelkhand Region, Int. J. Life. Sci. Scienti. Res., 4(4), 19251933.

17. Rastogi, R.P. and Mehrotra, B.N. (2002) Glossary of Indian Medicinal Plants. National Institute of Science Communication, New Delhi, India. Symposium Series No. 588, Washington, DC, 8-18.

18. Sharma, V., Kumawat, T.K., Seth, R. and Sharma, A., (2014) A Review on Antidermatophytic Efficiency of Plant Essential Oils, Int. J. Pure App. Biosci. 2(6), 265-278

19. Singh, A. (2007) Herbal medicine-dream unresolved, Pharmacognosy Reviews, 2, 375376

20. Vaidya, A.B. (1997) The status and scope of Indian medicinal plants acting on central nervous system, Indian J Pharmacol. 29,340-3. 